\title{
Review
}

\section{The case for the introduction of new chemotherapy agents in the treatment of advanced non small cell lung cancer in the wake of the findings of The National Institute of Clinical Excellence (NICE)}

\author{
JS Waters ${ }^{1,2}$ and MER O'Brien ${ }^{* 1,2}$ \\ 'Lung Unit, The Royal Marsden Hospital, Sutton, Surrey, UK; ${ }^{2}$ Kent Cancer Centre, Maidstone, Kent, UK
}

\begin{abstract}
After years of nihilism towards the use of chemotherapy for non small cell lung cancer in the UK it would appear that we have now reached the point where the use of chemotherapy to relieve symptoms, maintain quality of life, and prolong life, are now accepted for informed patients with good performance status willing to accept short-term toxicities. The use of the new agents vinorelbine, gemcitabine and paclitaxel in combination with cisplatin or carboplatin are all active regimens which offer small but real advantages over standard UK triple therapies (MVP, MIC) in terms of resource use, toxicity profiles and response rates. Overall survival could be increased by as much as $10 \%$ at one year on indirect comparisons. The use of docetaxel as second line therapy now offers lung cancer patients a second bite of the cherry, and should overall also prolong survival. It is only in embracing these small gains that we can currently make progress in the treatment of NSCLC. British Journal of Cancer (2002) 87, 48I -490. doi:10.1038/sj.bjc.660049I www.bjcancer.com

(c) 2002 Cancer Research UK
\end{abstract}

Keywords: Lung cancer; chemotherapy; non small cell lung cancer; NICE

The widespread nihilism in the UK towards palliative lung cancer treatment has meant that patients with all stages of lung cancer have been deprived of treatment that adds small survival gains and improved symptom relief. This may contribute to the overall dismal outcome survival figures for lung cancer in the UK (Janssen-Heijnen et al, 1998). At this time chemotherapy is sufficiently active to justify its use in patients of good performance status who understand the true goals of chemotherapy and its potential toxicities - but what should we use? The current questions regarding palliative chemotherapy in the UK remain - is any doublet of the new or old generation better than UK triple therapy for patients of performance status zero or one, and can single agent chemotherapy replace UK triple therapy for patients of performance status two? This review will examine the data in support of the new agents that have been assessed by the National Institute of Clinical Excellence in an attempt to answer these questions.

\section{CURRENT STANDARDS}

The commonest (standard) treatments for non-small cell lung cancer (NSCLC) in this country are cisplatin based, usually MVP (mitomycin C, vinblastine and cisplatin) or MIC (mitomycin C, iphosphamide and cisplatin) with cisplatin used at a dose of around $50-60 \mathrm{mg} \mathrm{m}^{-2}$. This differs to the United States where the cisplatin dose is usually higher and the combinations most frequently used until the late 1990s were etoposide plus cisplatin and vinblastine or vindesine with cisplatin. These regimens have been directly compared in several trials. One of these trials

*Correspondence: MER O'Brien; Lung Unit, The Royal Marsden Hospital, Downs Road, Sutton, Surrey, SM2 5PT, UK; E-mail: maryo@icr.ac.uk

Received 2I January 2002; revised I5 April 2002; accepted I9 May 2002 compared MIC, MVP and etoposide/cisplatin and showed a significant survival advantage for both three drug regimens (median survival 36 weeks, 42 weeks, and 27 weeks respectively; $P<0.04$ ) (Crino et al, 1995). Other randomised trials did not report any advantages with the cisplatin triplets (Ruckdeschel et al, 1986; Crino et al, 1990).

The use of higher cisplatin doses was based on one small randomised trial involving 85 patients, that demonstrated a longer duration of response and a survival advantage for responders in the higher dose arm but overall survival was not reported (Gralla et al, 1981). However, three subsequent larger randomised studies have failed to show an advantage for the higher cisplatin doses and toxicity was considerably worse (Table 1) (Gandara et al, 1993; Klastersky et al, 1986; Felip et al, 1997). Thus UK oncologists tend to use cisplatin at a dose of $50 \mathrm{mg} \mathrm{m}^{-2}$ in triple therapy given three-weekly, and this is also well tolerated by performance status-two patients (Smith et al, 2001).

The standard duration of chemotherapy has also recently been challenged. A trial of MVP chemotherapy showed that three courses produced the same symptomatic benefits and response rates as six. Haematological toxicity increased during courses four to six in patients randomised to receive six courses with grade $3-4$ leucopenia in $22 \%$ and grade 3-4 thrombocytopenia in $7 \%$ compared with $12 \%$ and $1 \%$ respectively in the patients randomised to receive three courses (Smith et al, 2001). The median survival was 6 vs 7 months in the two arms, and the 1-year survival was $22 \%$ vs $25 \%(P=0.2)$. In the subgroup of patients of performance status 0 and 1 the 1-year survival was no different at $25.6 \%$ (95\% CI, 20.8-32.5\%), and performance status did not come out as an independent prognostic factor in this trial. Quality of life deteriorated after the fourth course in the group having six courses of chemotherapy. These results were corroborated by a recently reported trial comparing treatment with a combination of carboplatin and paclitaxel for four cycles or continued until 
disease progression. Survival and quality of life were the same in the two treatment arms, as was the median number of chemotherapy cycles delivered (Socinski et al, 2001). Most centres now treat NSCLC with 3-4 courses of palliative chemotherapy. This of course has major health economic implications.

In patients who are not suitable for cisplatin based treatment, carboplatin can be used instead on the basis that for most solid tumours carboplatin produces similar palliative benefits to cisplatin. The three-drug combination mitomycin $\mathrm{C}$, vinblastine and carboplatin (MVCarbo) is given as a day case, and appears to be as active as MVP but with more myelosuppression, with rates of grade 3-4 leucopenia of $24 \%$ and grade 3-4 thrombocytopenia of 22\% (Gregory et al, 2001). The drug costs for MVCarbo are about the same as for single agent vinorelbine or gemcitabine. Two randomised trials have addressed whether carboplatin can replace cisplatin in standard lung cancer chemotherapy regimens. The first trial, conducted by the EORTC, evaluated cisplatin or carboplatin in combination with etoposide, using a cisplatin dose of $120 \mathrm{mg} \mathrm{m}^{-2}$ and a carboplatin dose of $325 \mathrm{mg} \mathrm{m}^{-2}$ (Klastersky et al, 1990). Two hundred and twenty-eight eligible patients were randomised among whom response rates were $16 \%$ in the carboplatin arm and $27 \%$ in the patients treated with cisplatin

Table I Comparison of high and low-dose cisplatin in untreated patients with non small cell lung cancer

\begin{tabular}{|c|c|c|c|c|}
\hline $\begin{array}{l}\text { Treatment } \\
\text { arms }\end{array}$ & Number & $\begin{array}{l}\text { Objective } \\
\text { response rate }\end{array}$ & $\begin{array}{c}\text { Mean survival } \\
\text { (months) }\end{array}$ & Reference \\
\hline $\begin{array}{l}\text { VdCis }(60) \\
\text { VdCis }(120)\end{array}$ & 85 & $\begin{array}{l}46 \% \\
40 \%\end{array}$ & $\begin{array}{l}10 \text { (in responders) } \\
22 \text { (in responders) }\end{array}$ & $\begin{array}{l}\text { Gralla et al, } \\
\mid 981\end{array}$ \\
\hline $\begin{array}{l}\text { ECis (60) } \\
\text { ECis }(120)\end{array}$ & 241 & $\begin{array}{l}25 \% \\
29 \%\end{array}$ & NS & $\begin{array}{c}\text { Klastersky et al, } \\
1986\end{array}$ \\
\hline $\begin{array}{l}\text { Cis }(50 \mathrm{dl}+8) \\
\text { Cis }(100 \mathrm{dl}+8) \\
\text { MCis }(100 \mathrm{dl}+8)\end{array}$ & 356 & $\begin{array}{l}12 \% \\
14 \% \\
27 \%(P<0.05)\end{array}$ & $\begin{array}{l}6.9 \\
5.3 \\
7.2(P=0.53)\end{array}$ & $\begin{array}{l}\text { Gandara et al, } \\
1993\end{array}$ \\
\hline $\begin{array}{l}\text { MICis }(50)^{\mathrm{a}} \\
\text { MICis }(100)^{\mathrm{a}}\end{array}$ & 72 & $\begin{array}{l}48 \% \\
\text { NS }\end{array}$ & NS & $\begin{array}{c}\text { Felip et al, } \\
1997\end{array}$ \\
\hline
\end{tabular}

aPreoperative chemotherapy for stage IIIA NSCLC; Vd=vindesine; Cis=cisplatin $\mathrm{E}=$ =toposide; $\mathrm{M}=$ =mitomycin $\mathrm{C}$; NS=no significant difference between arms; Figures in brackets refer to cisplatin dose in $\mathrm{mg} \mathrm{m}^{-2}$ - all regimens are 3-weekly except days $1+8$ regimens which are 4-weekly.
$(P=0.07)$. No survival difference was demonstrated (median survival 27 vs 30 weeks; $P=0.35$ ), and higher rates of toxicity were seen with the cisplatin regimen. In the second trial involving 221 patients, the regimen investigated was mitomycin, vinblastine and platinum, using either cisplatin $120 \mathrm{mg} \mathrm{m}^{-2}$ or carboplatin $500 \mathrm{mg} \mathrm{m}^{-2}$ (Jelic et al, 2001). Thus the carboplatin: cisplatin dose ratio was greater in this study. Response rates were identical in the two arms (37\% vs $36 \% ; P>0.9)$, but both progression-free survival $(P=0.005)$ and overall survival $(P=0.008)$ favoured the carboplatin regimen. The authors do not report median survival times or the proportion of patients surviving for 1 year and it is therefore difficult to ascertain the clinical relevance of this difference. Furthermore, a significant imbalance between the two arms was found in relation to performance status, with a significantly greater proportion of performance status 0 and 1 patients in the carboplatin arm. In this trial the carboplatin regimen produced significantly more haematological toxicity whereas the cisplatin regimen was more emetogenic. On a cautionary note, a numerically inferior survival was produced by a regimen of carboplatin and docetaxel compared with a cisplatin/docetaxel combination (median survival 9.1 months vs 10.9 months). However, this randomised trial was designed to compare each of these regimens with a control arm of cisplatin plus vinorelbine and was not powered to examine the difference between the two docetaxel-containing arms (Rodriguez et al, 2001). The carboplatin/cisplatin debate goes on and a trial to definitively answer this question will need careful design and large numbers of patients.

\section{BACKGROUND TO THE NEW DRUGS}

Gemcitabine, the taxanes (paclitaxel, docetaxel), and vinorelbine all have significant single agent activity with response rates of at least $20 \%$ and encouraging survival data with acceptable toxicities. It is gratifying to see that they have all been tested against best supportive care in NSCLC (Table 2). Similarly all four drugs have been combined with cisplatin with predictable toxicity and higher response rates than are achieved with cisplatin alone - this data will not be enlarged upon as single agent cisplatin is not a usual therapy in the UK. On the other hand there is little data on the use of a new agent with cisplatin versus a new agent alone, vinorelbine being the drug with the most data on this issue to date. However a recently completed study in the US compared paclitaxel plus cisplatin with single agent paclitaxel, and the results are awaited with interest (Lilenbaum et al, 2001). More recently a

Table 2 Chemotherapy vs Best Supportive Care (BSC) in untreated patients with non small cell lung cancer

\begin{tabular}{|c|c|c|c|c|c|c|c|c|}
\hline & Number & PS & $\begin{array}{c}\text { Objective } \\
\text { response rate }\end{array}$ & $\begin{array}{l}\text { Median survival } \\
\text { (months) }\end{array}$ & $\begin{array}{l}\text { I-year } \\
\text { survival }\end{array}$ & $\begin{array}{l}\text { Quality } \\
\text { of life }\end{array}$ & Symptoms & s Reference \\
\hline $\begin{array}{l}\text { Cisplatin } \\
\text { BSC }\end{array}$ & 778 & $N R$ & $N R$ & $\begin{array}{l}1 \\
2.5\end{array}$ & $\begin{array}{r}15 \% \\
5 \%\end{array}$ & $N R$ & NR & $\begin{array}{l}\text { Meta-analysis } \\
1995\end{array}$ \\
\hline $\begin{array}{l}\text { MIC } \\
\text { BSC }\end{array}$ & 351 & $0-2$ & $32 \%$ & $\begin{array}{l}6.7 \\
4.8\end{array}$ & $\begin{array}{l}25 \% \\
17 \%(P=0.03)\end{array}$ & + & + & Cullen, 1999 \\
\hline $\begin{array}{l}\text { MVP/IEP } \\
\text { BSC }\end{array}$ & 287 & $0-2$ & $\begin{array}{c}42 \% / 40 \% \\
-\end{array}$ & $\begin{array}{l}8.1 / 5.9 \\
4.1 \quad(P=0.0003)\end{array}$ & $\begin{array}{l}39 \% / 30 \% \\
13 \%\end{array}$ & + & NR & Thongprasert, 1999 \\
\hline $\begin{array}{l}\text { Vinorelbine } \\
\text { BSC }\end{array}$ & $|6|$ & $0-2$ & $\begin{array}{c}19.7 \% \\
-\end{array}$ & $\begin{array}{l}6.75 \\
5.25(P=0.03)\end{array}$ & $\begin{array}{l}32 \% \\
14 \%(P=0.04)\end{array}$ & + & + & Gridelli, 1999 \\
\hline $\begin{array}{l}\text { Gemcitabine } \\
\text { BSC }\end{array}$ & 300 & $0-2$ & $\begin{array}{l}33 \%^{\mathrm{a}} \\
12.7 \%^{\mathrm{a}}\end{array}$ & & NS & + & + & Anderson, 1999 \\
\hline $\begin{array}{l}\text { Paclitaxel } \\
\text { BSC }\end{array}$ & 157 & $0-2$ & $16 \%$ & $\begin{array}{l}6.8 \\
4.8\end{array}$ & $\begin{array}{l}32 \% \\
25 \%\end{array}$ & + & NR & Ransom, 2000 \\
\hline $\begin{array}{l}\text { Docetaxel } \\
\text { BSC }\end{array}$ & 207 & $0-2$ & $\begin{array}{c}13.1 \% \\
-\end{array}$ & $\begin{array}{l}6 \\
5.7\end{array}$ & $\begin{array}{l}25 \% \\
16 \%(P=0.026)\end{array}$ & + & + & Roszkowski et al, 2000 \\
\hline
\end{tabular}

aSymptom response; $M=$ mitomycin $C ; I=$ iphosphamide; $C=$ cisplatin; $V=$ vinblastine; $E=$ etoposide; $N R=$ not reported; NS=not significant; +=improvement in parameter. 
number of doublets have been compared with each other in randomised trials.

\section{CLINICAL EFFECTIVENESS OF VINORELBINE}

\section{Vinorelbine $v s$ best supportive care}

A large randomised phase III trial, compared vinorelbine to best supportive care alone in 191 elderly patients (over 70 years) with NSCLC stages IIIb or IV, WHO performance status 0-2 (Elderly Lung Cancer Vinorelbine Italian Study Group, 1999). The primary end point was improvement in quality of life. Secondary endpoints were toxicity and tumour response in the vinorelbine arm. Vinorelbine treated patients had an improved quality of life, measured as improvement in physical, cognitive and social functioning compared to patients treated with best supportive care only. Treated patients also recorded improvements in disease related symptoms (cough, dyspnoea, pain, fatigue) but worse toxicityrelated symptoms (constipation, nausea and vomiting, peripheral neuropathy and hair loss). Survival rates for the vinorelbine-treated patients at 6 and 12 months were 55\% and 32\%, compared to $41 \%$ and $14 \%$ in the control group. Median survival increased from 21 to 28 weeks $(P=0.03)$. After adjustment for stage of disease and performance status, the estimated relative hazard of death for the vinorelbine-treated patients was 0.65 (95\% confidence interval [CI], 0.45-0.93) compared to those in the control arm. The objective overall response rate (ORR) in the vinorelbine-treated patients was $19.7 \%$ with a further $30.3 \%$ having stable disease, while $42.1 \%$ had progressive disease. Vinorelbine treatment was generally well tolerated by the majority of patients. Only five patients stopped treatment due to toxicity (Elderly Lung Cancer Vinorelbine Italian Study Group, 1999) (Table 2).

A similar study of 211 patients with stage IV NSCLC randomised patients to either vinorelbine or a control arm of 5fluorouracil (5-FU) on a 2:1 ratio. The FDA chose the control arm of 5-FU, as it was not considered ethical to randomise against no treatment. The primary endpoints were survival and quality of life with response rates the secondary end point. The outcome favoured vinorelbine in terms of both median survival $\left(\begin{array}{ll}30 & \mathrm{vs} \\ 22\end{array}\right.$ weeks, $P<0.03$ ) and the proportion of patients alive at 1 year (25\% vs 16\%) (Crawford et al, 1996).

\section{Vinorelbine in combination with cisplatin $v s$ other standards}

Vinorelbine plus cisplatin has been compared with single agent vinorelbine. In a three-arm study, 612 patients of performance status 0,1 , and 2 were randomised between vinorelbine/cisplatin, vindesine/cisplatin and vinorelbine alone. The vinorelbine/cisplatin combination resulted in a significantly superior response rate and survival (Table 3) (Le Chevalier et al, 1994). More recent analysis of this data has shown that the subgroup of patients with performance status 2 had more toxicity and less benefit from vinorelbine and cisplatin when compared to vinorelbine alone (Le Chevalier et al, 2001). Two smaller randomised studies compared vinorelbine/cisplatin to vinorelbine alone and showed a

Table 3 New agents alone or in combination with platinum compared with standard regimens in untreated patients with stage IIIB and IV non small cell lung cancer

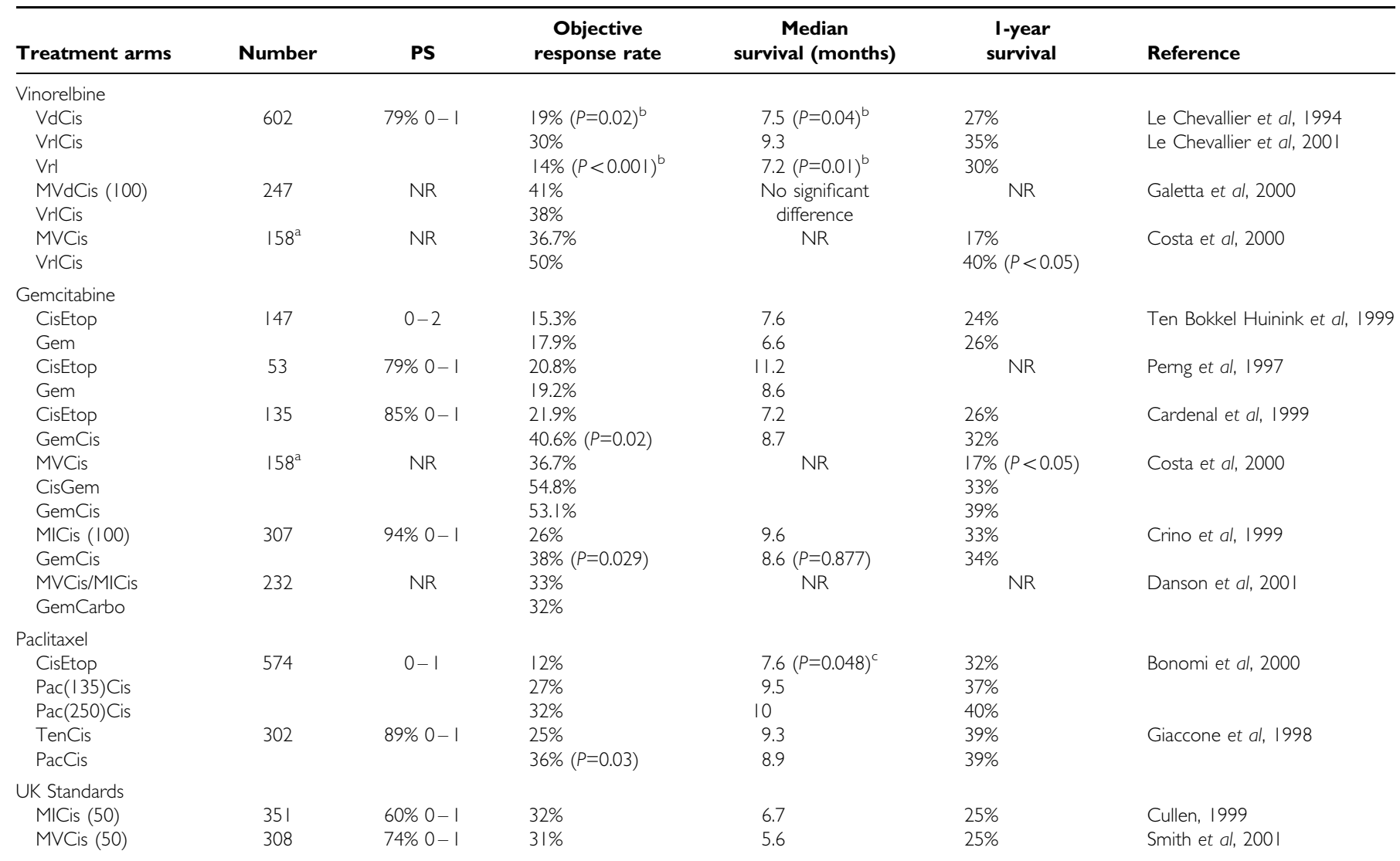

Vd=vindesine; Cis=cisplatin; Vrl=vinorelbine; $M=$ mitomycin C; $V=$ vinblastine; Etop=etoposide; Gem=gemcitabine; I=iphosphasmide; Carbo=carboplatin; Pac=paclitaxel; Ten=tenipsoide; NR=not reported; ${ }^{a}$ Total number of patients in 4-arm trial (see text); ${ }^{b}$ Compared to VriCis arm; ${ }^{\circ}$ Compared to combined paclitaxel arms. 
non significant trend to improved survival: 41 vs 33 weeks (Gil Deza et al, 1996), and 33 vs 32 weeks (Depierre et al, 1999).

Two randomised clinical trials have compared vinorelbine plus cisplatin with standard cisplatin-based triplets. An Italian group has recently updated their study and presented it at the World Lung Cancer Meeting in Japan in September 2000. A total of 247 patients have been randomised to cisplatin and vinorelbine (VrlCis) or MVdP (cisplatin $100 \mathrm{mg} \mathrm{m}^{-2}$, vindesine and mitomycin C). There was no statistically significant difference between response rates $(38 \% \mathrm{VrlCis}$ and $41 \% \mathrm{MVdP})$, time to progression or overall survival. The VrlCis arm had more phlebitis and the MVdP arm had more myelosuppression and thrombocytopenia. The authors concluded VrlCis was as active as MVdP but less toxic (Table 3) (Galetta et al, 2000).

A Portuguese group have reported on the first 158 patients of a planned 240 entered in a randomised Phase III trial comparing MVP (mitomycin, vinblastine, cisplatin) vs VrlCis (vinorelbine and cisplatin) vs CisGem (cisplatin $\mathrm{d} 1$ and gemcitabine) vs GemCis (gemcitabine and cisplatin $\mathrm{d} 15$ and q28). The results are detailed in Table 3, demonstrating the superior activity of cisplatin combined with vinorelbine or gemcitabine vs MVP. However, this study was reported early and may well be underpowered to show a survival benefit. Further details of the patient population are also required (Costa et al, 2000).

\section{CLINICAL EFFECTIVENESS OF GEMCITABINE}

Gemcitabine was launched in 1995 - the same year as the metaanalysis (Non-small Cell Lung Cancer Collaborative Group, 1995). Phase II studies in NSCLC showed both activity and symptom control. An overall response rate of $20 \%$ was observed in the Manchester/Copenhagen study (and verified by an independent oncology review board), and 51 out of 73 patients (70\%) reported an improvement in their tumour related symptoms (Anderson et al, 1994). Single agent gemcitabine has been studied in the elderly with advanced NSCLC (Pasquini et al, 1998; Ricci et al, 2000). Response rates and toxicity profiles were no different from other phase II studies of single agents in younger patients.

\section{Gemcitabine $v s$ best supportive care}

There is only one phase III study looking at single agent gemcitabine and comparing it to best supportive care (Anderson et al, 2000). This study randomised 300 patients and had as endpoints the degree and durability of symptom response. The response rate to gemcitabine was $19 \%$ (95\% CI, 13-27\%). Symptom response in the two arms was assessed at 2, 4, and 6 months and was significantly better in the gemcitabine treated patients at 2 and 4 months $(P=0.048$ and $P=0.034)$ but was no different at 6 months. There was a trend to improved QoL in the gemcitabine arm with deterioration in the control arm over the first 2-month period, and a significant reduction in the need for radiotherapy - $49 \%$ for gemcitabine-treated patients vs $79 \%$ for controls. The most impressive result in this study was the difference in the number of days in hospital between the two study arms. Patients receiving best supportive care required on average 2012 days in hospital and 247 in hospice compared with 1746 days in hospital and 183 days in hospice for gemcitabine treated patients. There was no difference in survival between the treatment arms in this study but the study was underpowered to show this (Table 2).

\section{Gemcitabine $v s$ other standards}

A Taiwanese trial and a separate European study compared gemcitabine alone to etoposide/cisplatin. The response rates and survival were similar in both arms of both trials but the toxicity profile and inpatient days were markedly better in the gemcitabine arm (Perng et al, 1997; ten Bokkel Huinink et al, 1999). Similarily gemcitabine has been compared to cisplain and vindesine and again the single agent was less toxic and as effective (Vansteenkiste et al, 2000). These studies suggest gemcitabine can replace the older cisplatin doublets in the palliative treatment of NSCLC - we do not know if it can replace triplets including cisplatin and mitomycin $\mathrm{C}$.

\section{Gemcitabine in combination with cisplatin $v s$ other standard regimens}

Gemcitabine/cisplatin is more active than cisplatin alone with a response rate of $30.4 \%$ vs $11.1 \%(P<0.0001)$ and a median survival of 9.1 months versus 7.6 months. However, the combination is more toxic for all haematological parameters (Sandler et al, 2000). A Spanish study has compared gemcitabine/cisplatin (GemCis) to cisplatin/etoposide (Cis/Etop). This study had both quality of life and pharmacoeconomic analyses but for a phase III study the number of patients included was small at 135 in total. The response rate was higher with the new combination $(40.6 \%$ vs $21.9 \%, P=0.02$ ), the median duration of response was prolonged by 6 weeks but the overall survival was not different and the authors concluded the trial was underpowered to show a survival difference (Table 3). Neutropenia was more common with Cis/ Etop while thrombocytopenia was more common with GemCis. The quality of life showed no difference between the two treatments (Cardenal et al, 1999) and pharmacoeconomic data is also available (see cost effectiveness section) (Sacristan et al, 2000).

The most relevant trials for the UK are the comparisons of GemCis/GemCarbo to MIC/MVP. There are now three completed studies and a fourth in which this comparison is part of the four arm design. In the first reported by an Italian group (Table 3) (Crino et al, 1999), the MIC used differed from the UK MIC in that the cisplatin dose was $100 \mathrm{mg} \mathrm{m}^{-2}$ every 4 weeks while in the UK the dose is $50-60 \mathrm{mg} \mathrm{m}^{-2}$ every 3 weeks. There were 307 patients randomised in this study. The overall response rate was $38 \%$ for $\mathrm{GemCis} v s 26 \%$ for $\mathrm{MIC}(P=0.029)$. The median survival time was 8.6 months $v s \quad 9.6$ months respectively $(P=0.877)$. The incidence of severe neutropenia and anaemia was the same for both arms but there was more severe thrombocytopenia with the GemCis treatment, $64 \%$ vs $28 \%(P<0.001)$ and more alopecia with MIC, $12 \%$ vs $39 \%(P<0.001)$. The quality of life results were not different between the two treatment arms. Surprisingly this has lead to a change in practice in a number of European countries with widespread usage of gemcitabine and cisplatin.

A UK study reported in abstract form compared a carboplatin/ gemcitabine regimen with MIC or MVP (Table 3) (Danson et al, 2001). At the time of this report, the outcome of 232 patients was analysed, although over 300 patients had been enrolled in the trial. Response rates were equivalent in the two arms $(32 \%$ vs $33 \%$ ) with rates of stable disease slightly higher in the triplet arm $(26 \%$ vs 39\%). Toxicity was reported to be similar between the two groups although the gemcitabine/carboplatin arm produced higher rates of haematological toxicity $(P=0.006)$. Survival data are awaited. The third study addressing this question is also from the UK and has just been completed by the London Lung Group. Again data should be available this year. Finally, as discussed in the section on vinorelbine above, two different schedules of cisplatin and gemcitabine were demonstrated to produce higher response rates than MVP in a small four arm Portuguese trial (Table 3) (Costa et al, 2000).

\section{CLINICAL EFFECTIVENESS OF PACLITAXEL}

\section{Paclitaxel $v s$ best supportive care}

In one UK based trial 157 patients with advanced NSCLC, newly diagnosed, with performance status 0,1 or 2 were randomised to 
single agent paclitaxel or best supportive care. The primary endpoint was survival and this was statistically significantly improved in the patients receiving paclitaxel with a median survival of 6.8 months in the paclitaxel arm and 4.8 months in the best supportive care arm $(P=0.037)$. Quality of life was similar for both treatment arms apart from the functional activity score of the Rotterdam Symptom Checklist which was statistically in favour of the paclitaxel arm $(P=0.043)$ (Table 2) (Ranson et al, 2000).

\section{Paclitaxel in combination with cisplatin $v s$ other standard regimens}

The first of the studies using paclitaxel (Taxol) in combination with cisplatin started to appear around 1996. The ECOG study compared two doses of paclitaxel $\left(250\right.$ and $\left.135 \mathrm{mg} \mathrm{m}^{-2}\right)$ with cisplatin to etoposide/cisplatin (Bonomi et al, 2000). Both paclitaxel/cisplatin doses resulted in similar response rates, which were higher than the etoposide/cisplatin arm (32\% vs $27 \%$ vs $12 \%)$. The median survival was extended by about 2 months (10 vs 9.6 vs 7.7 months, $P=0.048)$ in the paclitaxel/cisplatin arms with an improvement in the 1-year survival ( $39 \%$ vs $37 \%$ vs $32 \%)$. The EORTC conducted a two-arm study comparing cisplatin and paclitaxel to cisplatin and teniposide and although the overall response rate was higher with the paclitaxel treatment $(36 \%$ vs $25 \%$, $P=0.03$ ), there was no survival difference between the two arms. The quality of life was superior in the paclitaxel arm at 6 weeks but this was lost at 12 weeks (Giaccone et al, 1998).

\section{CLINICAL EFFECTIVENESS OF DOCETAXEL}

Although NICE did not evaluate docetaxel as a first line treatment option, some data exists regarding its use in this setting. For completeness this is reviewed below.

\section{Docetaxel $v s$ best supportive care}

There is only one phase III study looking at single agent docetaxel and comparing it to best supportive care (Roszkowski et al, 2000). This study randomised 207 patients to either docetaxel at a dose of $100 \mathrm{mg} \mathrm{m}^{-2}$ or best supportive care. Patients of performance status 0,1 , and 2 were all included. The response rate to docetaxel was $13.1 \%(95 \% \mathrm{CI}, 7.5-18.8 \%)$ and $19.6 \%$ in the evaluable patients. Symptom response (pain and dyspnoea) was significantly better in the docetaxel treated patients with less use of opiate analgesics $(P<0.001)$ and less need for palliative radiotherapy $(P<0.01)$. There was a trend to improved quality of life in the docetaxel arm for global health and physical functioning scores.
The emotional functioning was significantly in favour of docetaxel $(P=0.01)$. There was a statistically significant improvement in median survival in docetaxel-treated patients, with a median survival of 6 months compared to 5.7 months $(P=0.026)$. This translated to an improved 1-year survival rate of $25 \%$ compared to $16 \%$ with best supportive care. At 2 years, $12 \%$ of the docetaxel patients were alive whereas none remained alive after 20 months in the best supportive care arm (Table 2).

\section{Docetaxel in combination with cisplatin $v s$ other standard regimens}

There is an ongoing trial comparing docetaxel plus cisplatin with the standard regimens MVP or MIC in the UK. This combination has been more extensively investigated in trials comparing the different new doublet regimens, and will be discussed below.

\section{TRIALS COMPARING THE NEW DRUG COMBINATIONS}

The favourable results with the newer agents discussed above has led to these 'platinum/new agent doublets' being adopted as standard chemotherapy regimens for advanced NSCLC in the United States and in parts of Europe. Several trials have now been conducted to examine whether any of these regimens stands out as being superior to the rest. The majority of these trials have only been the subject of reports in abstract form, and the mature results are awaited. However, in general, little difference in efficacy has been observed between the regimens studied, while differences in toxicity have largely been qualitative rather than quantitative.

\section{Comparisons of platinum-containing doublets}

At ASCO 2000 the first results of the long awaited ECOG 1594 trial were reported. This is one of the biggest trials in the palliative treatment of lung cancer and has recruited over 1000 patients (Schiller et al, 2000, 2002). The primary endpoint was survival. There were no formal quality of life assessments or cost comparisons. Initially patients with performance status 0,1 , and 2 were included. However, the poor outcome and toxicity in the performance status 2 group resulted in this group being excluded from the trial (Johnson et al, 1999; Schiller et al, 2002). The four treatments compared were cisplatin/paclitaxel, cisplatin/gemcitabine, carboplatin/paclitaxel and cisplatin/docetaxel. Table 4 shows the results. The response rates were of the order of $20 \%$, the median survivals were all the same, and the percentage alive at 1 year was $31-36 \%$. The time to progression was 1 month better for

Table 4 Comparisons of platinum-containing doublets in untreated patients with stage IIIB and IV non small cell lung cancer

\begin{tabular}{|c|c|c|c|c|c|c|}
\hline Treatment arms & Number & PS & Objective response rate & Median survival (months) & I-year survival & Reference \\
\hline GemCis & 1207 & $0-1^{a}$ & $22 \%$ & 8.1 & $36 \%$ & ECOG, 1594 \\
\hline DocCis & & & $17 \%$ & 7.4 & $31 \%$ & Schiller et al, 2002 \\
\hline $\mathrm{Pac}(24) \mathrm{Cis}$ & & & $21 \%$ & 7.8 & $31 \%$ & \\
\hline $\operatorname{Pac}(3)$ Carbo & & & $17 \%$ & 8.1 & $34 \%$ & \\
\hline $\mathrm{VrlCis}$ & 408 & $0-1$ & $27 \%$ & 8 & $36 \%$ & SWOG, 9509 \\
\hline $\operatorname{Pac}(3)$ Carbo & & & $27 \%$ & 8 & $38 \%$ & Kelly et al, 200I \\
\hline $\mathrm{VrlCis}$ & 1218 & KPS & NR & 10.0 & $42 \%$ & TAX 326 study \\
\hline DocCis & & $80-100$ & & $10.9(P=0.05)^{b}$ & $47 \%$ & Rodriguez et al, 2001 \\
\hline DocCarbo & & & & $9.1(P>0.05)^{b}$ & $38 \%$ & \\
\hline VriCis & 612 & $0-1$ & $31 \%$ & 9.5 & $37 \%$ & Scagliotti et al, 200। \\
\hline GemCis & & & $30 \%$ & 9.8 & $37 \%$ & \\
\hline $\operatorname{Pac}(3)$ Carbo & & & $32 \%$ & 9.9 & $43 \%$ & \\
\hline
\end{tabular}

Gem=gemcitabine; Cis=cisplatin; Pac=paclitaxel; Carbo=carboplatin; Vrl=vinorelbine; Doc=docetaxel; KPS=Karnofski performance status; ${ }^{a}$ nitially included PS 2 patients; ${ }^{\mathrm{b}}$ Compared to $\mathrm{VriC}$ is arm. 
the cisplatin/gemcitabine arm, which reached statistical significance $(P=0.001)$.

In the South West Oncology Group (SWOG), vinorelbine (25 $\mathrm{mg} \mathrm{m}^{-2}$ week $^{-1}$ ) and cisplatin $\left(100 \mathrm{mg} \mathrm{m}^{-2}\right.$ every 4 weeks) was considered the standard chemotherapy. Their 9509 study compared this arm with three-weekly paclitaxel $\left(225 \mathrm{mg} \mathrm{m}^{-2}\right)$ plus carboplatin (AUC 6), as used in the ECOG study. The objective response rate and median survival time were equivalent $(27 \%$ and 8 months) and the 1-year survival similar (36\% compared to $38 \%$; $P$ value, not significant) (Table 4). Quality of life was similar with approximately $60 \%$ of patients having improved or stable quality of life scores on both arms of the study. Toxicity appeared to be greater among patients receiving cisplatin/vinorelbine, with significantly higher rates of severe neutropenia, leucopenia, nausea and vomiting, whereas sensory neuropathy occurred significantly more frequently in the paclitaxel/carboplatin arm. This led to discontinuation of therapy due to toxicity in $28 \%$ of patients treated with cisplatin/vinorelbine compared with $15 \%$ of those receiving paclitaxel/carboplatin. However, the cost of treatment with paclitaxel/carboplatin is several fold higher (Kelly et al, 2001).

The cisplatin/vinorelbine regimen has also acted as the standard arm in two European studies, both enrolling patients of performance status 0 and 1, and both reported at ASCO 2001. The TAX 326 study was a large three arm trial in which the two other regimens examined were docetaxel $\left(75 \mathrm{mg} \mathrm{m}^{-2}\right)$ plus cisplatin $\left(75 \mathrm{mg} \mathrm{m}^{-2}\right)$ every 3 weeks and docetaxel $\left(75 \mathrm{mg} \mathrm{m}^{-2}\right)$ plus carboplatin (AUC 6) every 3 weeks. This trial demonstrates an improved quality of life with the lower dose of cisplatin but no statistically significant survival difference between arms after application of the Bonferoni correction for multiple statistical tests. The median survival was 10.9 months in the docetaxel/cisplatin arm compared with 10 months in the cisplatin/vinorelbine arm $(P=0.05)$. The outcome in the docetaxel/carboplatin arm was not statistically different from that in the cisplatin/vinorelbine arm with a median survival of 9.1 months, and the rate of toxicity was lowest in this arm (Fossella, 2001; Rodriguez et al, 2001). The second study compared the same control arm of vinorelbine and cisplatin with two other doublets, gemcitabine $\left(1250 \mathrm{mg} \mathrm{m}^{-2}\right.$ days 1 and 8 ) plus cisplatin (75 $\mathrm{mg} \mathrm{m}^{-2}$ day 2), and carboplatin (AUC 6, day 1) plus paclitaxel (225 $\mathrm{mg} \mathrm{m}^{-2}$ day 1$)$, each on a three-weekly cycle. The results are also shown in Table 4 and demonstrate no significant outcome differences between the three arms (Scagliotti et al, 2001).

\section{Doublets without platinum}

The perceived toxicity of platinum drugs has also led researchers to investigate whether these can be omitted altogether. Two randomised trials have investigated the combination of paclitaxel and gemcitabine, and compared it with platinum-based doublets (Table 5). An EORTC three-arm trial compared three-weekly paclitaxel (175 $\mathrm{mg} \mathrm{m}^{-2}$ day 1) plus cisplatin $\left(\mathrm{mg} \mathrm{m}^{-2}\right.$ day 1$) v s$ gemcitabine $\left(1250 \mathrm{mg} \mathrm{m}^{-2}\right.$ days 1 and 8$)$ plus cisplatin $\left(80 \mathrm{mg} \mathrm{m}^{-2}\right.$ day 1) vs paclitaxel (175 $\mathrm{mg} \mathrm{m}^{-2}$ day 1) plus gemcitabine $\left(1250 \mathrm{mg} \mathrm{m}^{-2}\right.$ days 1 and 8) (Van Meerbeeck et al, 2001). The differences between these regimens did not reach statistical significance, but there was a trend towards a worse overall survival duration in the paclitaxel/ gemcitabine arm. As expected, the rates of severe nausea and vomiting were lower in the paclitaxel/gemcitabine arm, but toxicity was otherwise similar. It should be noted that this trial was powered to detect a survival difference of $50 \%$ between regimens, and therefore, like many of the trials discussed, was underpowered to detect realistic small differences in efficacy. The second trial addressing this question was conducted in Greece, and compared three-weekly paclitaxel (200 $\mathrm{mg} \mathrm{m}^{-2}$ day 1) plus carboplatin (AUC 6 day 1) with paclitaxel $\left(200 \mathrm{mg} \mathrm{m}^{-2}\right.$ day 1) plus gemcitabine $\left(1000 \mathrm{mg} \mathrm{m}^{-2}\right.$ days 1 and 8$)$. This was also a relatively small trial, enrolling 329 patients, and no statistically significant outcome differences were observed. However, low rates of severe toxicity were seen in both arms of this study (Kosmidis et al, 2000). A third trial also conducted in Greece has compared the combination of docetaxel $\left(100 \mathrm{mg} \mathrm{m}^{-2}\right.$ day 8$)$ plus gemcitabine $\left(1100 \mathrm{mg} \mathrm{m}^{-2}\right.$ days 1 and 8$)$ with docetaxel $\left(100 \mathrm{mg} \mathrm{m}^{-2}\right.$ day 1) plus cisplatin $\left(80 \mathrm{mg} \mathrm{m}^{-2}\right.$ day 2$)$. Four hundred and forty-one patients were randomised between the two arms, and all were supported with granulocyte colony stimulating factor during chemotherapy. Response rates were similar in the two groups (30.2\% vs $32.4 \%$ ) and no differences were observed in time to tumour progression or survival (Table 5). However, docetaxel plus gemcitabine had a more favourable toxicity profile with significantly lower rates of grade 3 or 4 neutropenia, nausea and vomiting and diarrhoea (Georgoulias et al, 2001).

\section{Two $v s$ three drugs}

A further question that has been addressed is whether adding a third drug to existing doublets might enhance their activity. Thus, triplets comprising cisplatin, gemcitabine and vinorelbine, and cisplatin, gemcitabine and paclitaxel have been compared with a cisplatin/gemcitabine doublet. Results are preliminary at present, but no clear advantage of the three-drug regimens has emerged to date, and toxicity is greater in comparison with this doublet (Comella et al, 2000; Alberola et al, 2001). Similar results have been produced in a comparison between the triplet vinorelbine, iphosphamide, cisplatin and the doublet vinorelbine/cisplatin, with no advantage for the triplet combination (Tan et al, 2001).

\section{ELDERLY PATIENTS WITH NON-SMALL CELL LUNG CANCER}

Several trials have addressed the question of the optimal treatment for patients aged over 70 years. As discussed above in the section on vinorelbine, this drug was compared with best supportive care in this patient group and demonstrated palliative and survival benefits. Subsequently, single agent vinorelbine (30 $\mathrm{mg} \mathrm{m}^{-2}$ days 1 and 8 ) was compared with a combination

Table 5 Evaluation of non-platinum doublets in untreated patients with stage IIIB and IV non small cell lung cancer

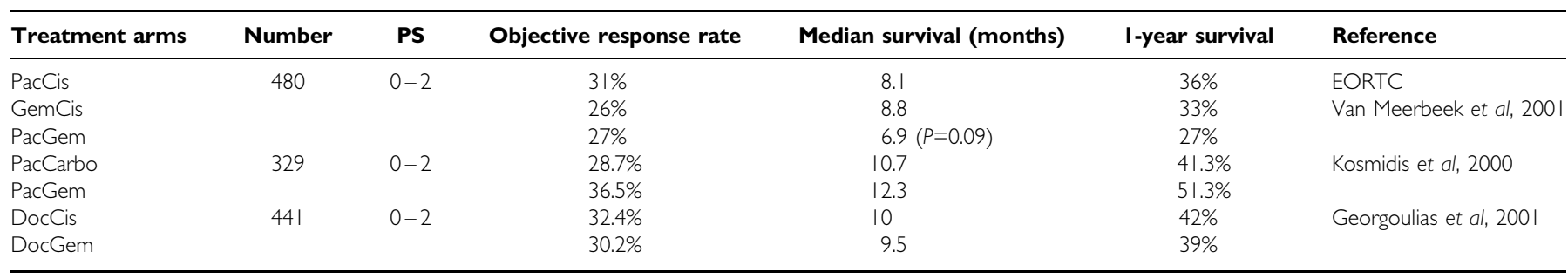

Pac=paclitaxel; Cis=cisplatin; Gem=gemcitabine; Carbo=carboplatin; Doc=docetaxel. 
of vinorelbine (30 $\mathrm{mg} \mathrm{m}^{-2}$ days 1 and 8 ) and gemcitabine (1000 $\mathrm{mg} \mathrm{m}^{-2}$ days 1 and 8 ), with both regimens given on a three-weekly cycle. Planned enrolment was 240 patients, but the trial was stopped early following a planned interim analysis after the accrual of 152 patients, and analysis of response rates and survival for the first 120 patients entered in the trial. This demonstrated the superiority of the combination treatment, with a median overall survival of 29 weeks compared with 18 weeks in the single agent vinorelbine arm, and a relative risk of death after Cox multivariate analysis of 0.48 (95\% CI $0.29-0.79$; $P<0.01)$. Toxicity was reported to show no significant differences between the two arms (Frasci et al, 2000). However, a second trial compared single agent vinorelbine with the combination of vinorelbine plus gemcitabine, and also incorporated a third arm comprising single agent gemcitabine. This trial included 698 patients and did not show any significant differences between the combination and either single agent in response rates, median overall survival or 1-year survival rates. Furthermore, this trial demonstrated higher rates of myelosuppression with the combination treatment (Gridelli et al, 2001).

\section{THE SECOND LINE TREATMENT OF NSCLC}

Until recently, no agents have been available for use as a second line chemotherapy for lung cancer. Docetaxel has now been licensed for this purpose in Europe and in the USA. Two multicentre randomised trials have examined docetaxel in the second line treatment of lung cancer. The first trial included 373 patients and compared docetaxel to a control arm of vinorelbine or iphosphamide. Neither of these drugs would be considered standard second line treatment in this country. Docetaxel at a dose of $75 \mathrm{mg} \mathrm{m}^{-2}$ prolonged survival at 1 year $(32 \%$ vs $19 \%, P=0.025)$, prolonged time to progression $(P=0.046)$ and prolonged the progression free survival $(P=0.005)$, but did not affect overall survival. Quality of life data has not been reported yet (Fossella et al, 2000).

The second trial including 104 patients, comparing docetaxel to supportive care alone, demonstrated a 2.4 month prolongation of survival with docetaxel plus supportive care compared to supportive care alone. Looking specifically at a docetaxel dose of $75 \mathrm{mg} \mathrm{m}^{-2}$ (which was better tolerated than $100 \mathrm{mg} \mathrm{m}^{-2}$ ) the median survival prolongation was 2.9 months ( 7.5 months vs 4.6 months; $P=0.01$ ) with an improved 1 year survival rate from $11 \%$ to $37 \%(P=0.003)$. Global health status assessed by the EORTC QLQ-C30 quality of life questionnaire favoured docetaxel. Outcomes were significantly better for pain and fatigue scales ( $P=0.006$ and $P=0.06$ respectively), time to deterioration in performance status, and there was a decreased need for analgesia $(P=0.01)$ and radiation therapy in the docetaxel arm. Toxicity with docetaxel was manageable and surprisingly not significantly different from patients receiving best supportive care alone (Shepherd et al, 2000). These improvements in outcome are comparable to those produced by irinotecan in the second line treatment of colon cancer (Cunningham et al, 1998), data that has been used to support the widespread adoption of this strategy in the UK (Table 6).

Table 6 Comparison of data in support of second line chemotherapy treatment for patients with metastatic colorectal cancer with irinotecan or stage IIIB/IV NSCLC with docetaxel

\begin{tabular}{lcc}
\hline & Irinotecan & Docetaxel \\
\hline No of patients in trials & 635 & 477 \\
Median survival gain (months) & 3 & 2.9 \\
I-year survival for treated patients & $36.2 \%$ & $37 \%$ \\
I-year survival for supportive care patients & $13.8 \%$ & $11 \%$ \\
Quality of life & Benefit & Benefit \\
\hline
\end{tabular}

\section{ECONOMIC ANALYSIS OF PALLIATIVE CHEMOTHERAPY}

The economic implications of palliative treatment for advanced NSCLC may be substantial as this is the commonest solid tumour in the UK and up to $40 \%$ of patients could become eligible for treatment in the next 3-5 years compared to an average of $8 \%$ currently. Most of the best health economic studies have been based in Canada. The POpulation HEalth Model (POHEM) is a model developed by the Health Analysis Modelling Group at Statistics Canada. This model looks at direct cost until death. Comparing cisplatin, doxorubicin and cyclophosphamide to best supportive care, the investigators showed a prolongation of life of the order of 8 weeks but with this there was a decrease in cost of the order of $\$ 949$ (Canadian dollars) per patient treated with chemotherapy due to the decreased need for hospitalisation (Jaakkimainen et al, 1990). The cost of treating a patient with best supportive care in Canadian dollars is $\$ 140895$ and the cost with vinblastine and cisplatin, single agent vinorelbine, outpatient vinorelbine and cisplatin, and outpatient etoposide and cisplatin were all less than this. Thus these strategies are referred to as 'dominant' in that they prolong survival and were less costly per life year saved (LYS). Inpatient treatment was more costly than best supportive care (Evans and Le Chevalier, 1996). A similar US based study with a best supportive care arm showed again vinorelbine with cisplatin was cost effective compared to vindesine and cisplatin providing one LYS at a cost of \$US15500 (Smith et al, 1995). However, while this is valid for regimens that are low cost, or with new single agents when compared to no chemotherapy, it may not be the case when these new agents are combined with cisplatin as patients may still need hospitalisation, and overall the treatments may become very much more expensive. In the US-ECOG trial (Bonomi et al, 2000), which showed some superiority of either paclitaxel/cisplatin regimen over cisplatin and etoposide, the cost per life year saved (LYS) was an additional $\$ 30619$ for the use of the paclitaxel regimen (Earle and Evans, 1999). In the SWOG 9509 trial that demonstrated equal efficacy between the two treatment arms, an economic analysis at 24 months demonstrated that the majority of the cost difference was due to the additional cost of chemotherapy between the two regimens tested. This was $\$ 11731$ for paclitaxel and cisplatin and $\$ 3498$ for vinorelbine and cisplatin for drug costs alone. All other supportive treatments e.g. blood products etc. were equal with the two treatments (Ramsey et al, 2000).

In Spain a combination of gemcitabine and cisplatin was no greater in total costs than MIC or cisplatin and etoposide (Cardenal et al, 1999; Sacristan et al, 2000). The cost of treating with chemotherapy compared to best supportive care translated from USA figures is about $\$ 15500$ per LYS which compares favourably with other health strategies e.g. dialysis for end stage renal failure at $\$ 53000$. It is also of the same order of magnitude as the use of taxanes for breast cancer, which when evaluated and approved

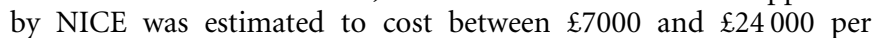
LYS. Health economic considerations change continually with changing practice in giving chemotherapy over time. For instance using rapid hydration to allow day case delivery of cisplatin reduces bed occupancy, or conversely the use of growth factors leads to higher costs.

There is only one UK study which details bed occupancy which is the major non drug expense and this is the Manchester based study comparing best supportive care to gemcitabine. Patients receiving best supportive care required on average 2012 days in hospital and 247 in hospice compared with 1746 days in hospital and 183 days in hospice for gemcitabine treated patients. In addition the gemcitabine treated patients required less radiotherapy (Anderson et al, 2000). This is of particular importance in the UK where delays in radiotherapy delivery are commonplace due to limited machine time. Second line treatment will be a new added treatment cost with continuing drug development, particu- 
larly if the promising new biological agents are brought successfully into clinical practice.

\section{CONCLUSIONS}

The National Institute for Clinical Excellence (NICE) has reviewed the use of chemotherapy for the palliative treatment of non small cell lung cancer in the year 2001. The volume of data on the use of chemotherapy, both new and old, is impressive. Unlike the treating doctors in the past, the committee felt that a prolongation of survival by $6-8$ weeks in a life that is predicted to be 6 months is important. The beneficial effects on quality of life and symptom control further increase the value of this treatment. Their evaluation of the new chemotherapy agents docetaxel, paclitaxel, gemcitabine and vinorelbine for this disease was therefore in function of this and their recommendations were that these drugs should be considered treatment options in accordance with their licences. Thus paclitaxel, vinorelbine and gemcitabine are all considered reasonable first-line treatment options in combination with cisplatin, and single-agent docetaxel is considered a suitable second-line therapy. They concluded that the current evidence is insufficient to allow recommendation of a specific first-line regimen as superior to the alternatives, but that patient and carer preferences as well as economic considerations should play a part in determining the appropriate treatment for an individual.
There remains considerable controversy as to whether the new drug combinations provide a significant advance over established UK regimens such as MVP and MIC, largely due to the lack of randomised clinical trials of sufficient power comparing these treatments. The results in terms of the percentage of patients alive at 1 year using MVP and MIC in UK-based phase III studies are included in Table 3. The disparity between these figures and those produced in recent trials of the new generation doublets could be due to differences in the patient populations between the UK trials and those conducted in North America and the rest of Europe. Alternatively, MIC and MVP may be truly less active regimens. For a two-arm trial to show a 5$8 \%$ difference in 1-year survival rate approximately 1000 patients would be required, and such trials have not been performed to date. Currently the market for these new agents is small in the UK compared to the market worldwide. It is therefore unlikely that the major pharmaceutical companies will fund these initiatives unless there is a suggestion that if the new treatments prove better they will become widely used and available. However, if we in the UK wish to move forward we cannot stall any more, and now have the mandate to treat. As more trials are reported and initiated we must have more money in the system so that the UK can be a participant or leader - this will not happen if we do not have regimens other than MIC and MVP on our menu of treatment options.

\section{REFERENCES}

Alberola V, Camps C, Provencia M, Isla D, Rosell R, Vadell C, Bover I, Ruiz Casado A, Azagra P, Jiménez U, González-Larriba JL, Cardenal F, Artal A, Carrato A, Morales S, Sánchez JJ (2001) Cisplatin/Gemcitabine (CG) vs Cisplatin/Gemcitabine/ Vinorelbine (CGV) vs Sequential Doublets of Gemcitabine/Vinorelbine followed by Ifosfamide/ Vinorelbine (GV/IV) in Advanced Non-Small Cell Lung Cancer (NSCLC): Results of a Spanish Lung Cancer Group Phase III Trial (GEPC/98-02). Proc Am Soc Clin Oncol 20: 308a (abstract)

Anderson H, Hopwood P, Stephens RJ, Thatcher N, Cottier B, Nicholson M, Milroy R, Maughan TS, Falk SJ, Bond MG, Burt PA, Connolly CK, McIllmurray MB, Carmichael J (2000) Gemcitabine plus best supportive care (BSC) vs BSC in inoperable non-small cell lung cancer-a randomized trial with quality of life as the primary outcome. UK NSCLC Gemcitabine Group. Non-Small Cell Lung Cancer. Br J Cancer 83: 447-453

Anderson H, Lund B, Bach F, Thatcher N, Walling J, Hansen HH (1994) Single-agent activity of weekly gemcitabine in advanced non-small-cell lung cancer: a phase II study. J Clin Oncol 12: 1821-1826

Bonomi P, Kim K, Fairclough D, Cella D, Kugler J, Rowinsky E, Jiroutek M, Johnson D (2000) Comparison of survival and quality of life in advanced non-small-cell lung cancer patients treated with two dose levels of paclitaxel combined with cisplatin versus etoposide with cisplatin: results of an Eastern Cooperative Oncology Group trial. J Clin Oncol 18: 623-631

Cardenal F, Lopez-Cabrerizo MP, Anton A, Alberola V, Massuti B, Carrato A, Barneto I, Lomas M, Garcia M, Lianes P, Montalar J, Vadell C, GonzalezLarriba JL, Nguyen B, Artal A, Rosell R (1999) Randomized phase III study of gemcitabine-cisplatin versus etoposide-cisplatin in the treatment of locally advanced or metastatic non-small-cell lung cancer. J Clin Oncol 17: $12-18$

Comella G, Comella P, Frasci G, Panza N, Nicolella GP, Manzione L, De Cataldis G, Cioffi R, Micillo E, Lorusso V, Bilancia D, Maiorino L, Piantedosi F, Mangiameli A, Gravina A, Lamberti A, De Lena M (2000) Cisplatin-Gemcitabine, vs. Cisplatin-Gemcitabine- Vinorelbine, vs. Cisplatin-Gemcitabine-Paclitaxel in Advanced Non-Small-Cell Lung Cancer. First-Stage Analysis of a Southern Italy Cooperative Oncology Group (SICOG) Phase III Trial. Proc Am Soc Clin Oncol 19: 494a (abstract)

Costa A, Barradas P, Cristova M, Alves P, Melo MJ (2000) Preliminary results of a randomised phase III trial comparing four cisplatin (P) based regimens in the treatment of locally advanced and metastatic non-small cell lung cancer (NSCLC). Lung Cancer 29(Suppl 1): 27 (abstract)
Crawford J, O'Rourke M, Schiller JH, Spiridonidis CH, Yanovich S, Ozer H, Langleben A, Hutchins L, Koletsky A, Clamon G, Burman S, White R, Hohneker J, Spiridonitis CH (1996) Randomized trial of vinorelbine compared with fluorouracil plus leucovorin in patients with stage IV non-small-cell lung cancer. J Clin Oncol 14: 2774-2784

Crino L, Clerici M, Figoli F, Carlini P, Ceci G, Cortesi E, Carpi A, Santini A, Di Costanzo F, Boni C, Meacci M, Corgna E, Darwish S, Scarcella L, Santucci A, Ballatori E, Tonato M (1995) Chemotherapy of advanced non-small-cell lung cancer: a comparison of three active regimens. A randomized trial of the Italian Oncology Group for Clinical Research (G.O.I.R.C.). Ann Oncol 6: $347-353$

Crino L, Scagliotti GV, Ricci S, De Marinis F, Rinaldi M, Gridelli C, Ceribelli A, Bianco R, Marangolo M, Di Costanzo F, Sassi M, Barni S, Ravaioli A, Adamo V, Portalone L, Cruciani G, Masotti A, Ferrara G, Gozzelino F, Tonato M (1999) Gemcitabine and cisplatin versus mitomycin, ifosfamide, and cisplatin in advanced non-small-cell lung cancer: A randomized phase III study of the Italian Lung Cancer Project. J Clin Oncol 17: $3522-3530$

Crino L, Tonato M, Darwish S, Meacci ML, Corgna E, Di Costanzo F, Buzzi F, Fornari G, Santi E, Ballatori E, Santucci C, Davis S (1990) A randomized trial of three cisplatin-containing regimens in advanced non-small-cell lung cancer (NSCLC): a study of the Umbrian Lung Cancer Group. Cancer Chemother Pharmacol 26: 52-56

Cullen MH, Billingham LJ, Woodroffe CM, Chetiyawardana AD, Gower NH, Joshi R, Ferry DR, Rudd RM, Spiro SG, Cook JE, Trask C, Bessell E, Connolly CK, Tobias J, Souhami RL (1999) Mitomycis, ifosfamide, and cisplatin in unresectable non-small-cell lung cancer: effects on survival and quality of life. J Clin Oncol 17(10): 3188-3194

Cunningham D, Pyrhonen S, James RD, Punt CJA, Hickish TF, Heikkila R, Johannesen T, Starkhammar H, Topham CA, Awad L, Jacques C, Herait P (1998) Randomised trial of irinotecan plus supportive care versus supportive care alone after fluorouracil failure for patients with metastatic colorectal cancer. Lancet 352: 1413-1418

Danson S, Clemons M, Middleton M, O'Byrne K, Hassan J, Anderson H, Burt P, Stout R, Swindell R, Dowd I, Beresford C, Thatcher N (2001) A Randomised Study of Gemcitabine with Carboplatin (GC) Versus Mitomycin, Vinblastine and Cisplatin (MVP) or Mitomycin C, Ifosfamide and Cisplatin (MIC) as First Line Chemotherapy in Advanced Non-Small Cell Lung Cancer (NSCLC). Proc Am Soc Clin Oncol 20: 322a (abstract) 
Depierre A, Milleron B, Moro D, Chevret S, Braun D, Quoix E, Lebeau B, Breton JL, Lemarié E, Gouva S, Paillot N, Bréchot JM, Janicot H, Lebas FX, Terrioux P, Foucher P, Monchâtre M, Coëtmeur D, Clavier J, Villeneuve A, Westeel V, Chastang C (1999) Phase III Trial of Neo-Adjuvant Chemotherapy (NCT) in Resectable Stage I (except T1N0), II, IIIa NonSmall Cell Lung Cancer (NSCLC): The French Experience. Proc Am Soc Clin Oncol 18: 465a (abstract)

Earle CC, Evans WK (1999) Cost-effectivenes of paclitaxel plus cisplatin in advanced non-small-cell lung cancer. Br J Cancer 80: 815-820

Elderly Lung Cancer Vinorelbine Italian Study Group (1999) Effects of vinorelbine on quality of life and survival of elderly patients with advanced nonsmall-cell lung cancer. J Natl Cancer Inst 91: 66-72

Evans WK, Le Chevalier T (1996) The cost-effectiveness of navelbine alone or in combination with cisplatin in comparison to other chemotherapy regimens and best supportive care in stage IV non-small cell lung cancer. Eur J Cancer 32A: 2249-2255

Felip E, Moreno I, Canela M, Alberola V, Gomez-Codina J, Gonzalez-Larriba JL, Anto A, Lopez-Cabrerizo MP, Maestre J, Rosell R (1997) Spanish lung cancer group randomised trial of preoperative chemotherapy (Cisplatin either $50 \mathrm{mg} / \mathrm{m} 2$ or $100 \mathrm{mg} / \mathrm{m} 2$ ) in stage IIIA (N2) non-small cell lung cancer. Lung Cancer 18(Suppl 1): 64 (abstract)

Fossella F (2001) Docetaxel + Cisplatin (DC) and Docetaxel + Carboplatin (DCB) vs Vinorelbine + Cisplatin (VC) in chemotherapy-naive patients with advanced and metastatic non-small cell lung cancer: Results of a multicenter, randomized phase III study. Eur J Cancer 37(Suppl 6): S154 (abstract)

Fossella FV, DeVore R, Kerr RN, Crawford J, Natale RR, Dunphy F, Kalman L, Miller V, Lee JS, Moore M, Gandara D, Karp D, Vokes E, Kris M, Kim Y, Gamza F, Hammershaimb L (2000) Randomized phase III trial of docetaxel versus vinorelbine or ifosfamide in patients with advanced non-smallcell lung cancer previously treated with platinum-containing chemotherapy regimens. The TAX 320 Non-Small Cell Lung Cancer Study Group. $J$ Clin Oncol 18: 2354-2362

Frasci G, Lorusso V, Panza N, Comella P, De Cataldis G, Micillo E, Iannelli N, Filippelli G, Muci D, Piantedosi FV, Belli M, Nicolella GP, Mascia V, Massidda B, Comella G, De Lena M (2000) Gemcitabine + Vinorelbine (GV) Yields Better Survival than Vinorelbine (V) Alone in Elderly NonSmall Cell Lung Cancer (NSCLC) Patients. Final Analysis of a Southern Italy Cooperative Oncology Group (SICOG) Phase III Trial. Proc Am Soc Clin Oncol 19: 485a (abstract)

Galetta D, Gebbia V, Riccardi F, Borsellino N, Gridelli C, Testa A, Durini E, Gebbia N, Colucci G (2000) A randomised phase III trial of the Southern Italy Oncology Group (GOIM) of mitomycin C plus vindesine and cisplatin (MVP regimen) versus vinorelbine plus cisplatin (PV regimen) in stage III-IV non small cell lung cancer. Lung Cancer 29(Suppl 1): 21 (abstract)

Gandara DR, Crowley J, Livingston RB, Perez EA, Taylor CW, Weiss G, Neefe JR, Hutchins LF, Roach RW, Grunberg SM, Braun TJ, Natale RB, Balcerzak SP (1993) Evaluation of cisplatin intensity in metastatic non-small-cell lung cancer: a phase III study of the Southwest Oncology Group. J Clin Oncol 11: 873-878

Georgoulias V, Papadakis E, Alexopoulos A, Tsiafaki X, Rapti A, Veslemes M, Palamidas P, Vlachonikolis I (2001) Platinum-based and non-platinumbased chemotherapy in advanced non-small-cell lung cancer: a randomised multicentre trial. Lancet 357: 1478 - 1484

Giaccone G, Splinter TA, Debruyne C, Kho GS, Lianes P, van Zandwijk N, Pennucci MC, Scagliotti G, van Meerbeeck J, van Hoesel Q, Curran D, Sahmoud T, Postmus PE (1998) Randomized study of paclitaxel-cisplatin versus cisplatin-teniposide in patients with advanced non-small-cell lung cancer. The European Organization for Research and Treatment of Cancer Lung Cancer Cooperative Group. J Clin Oncol 16: 2133-2141

Gil Deza E, Balbiani L, Coppola F, Blajman C, Block JF, Giachella O, Chacon R, Capo A, Zori Comba A, Fein L, Polera L, Matwiejuk M, Jaremtchuk A, Muro H, Reale M, Bass C, Chiesa G, Van Koten M, Schmilovich A (1996) Phase III study of Navelbine versus Navelbine plus cisplatin in non-small cell lung cancer stage IIIb or IV. Proc Am Soc Clin Oncol 15: 394 (abstract)

Gralla RJ, Casper ES, Kelsen DP, Braun Jr DW, Dukeman ME, Martini N, Young CW, Golbey RB (1981) Cisplatin and vindesine combination chemotherapy for advanced carcinoma of the lung: A randomized trial investigating two dosage schedules. Ann Intern Med 95: 414-420

Gregory K, Smith IE, Norton A, Ashley S, O’Brien MER (2001) Mitomycin C, vinblastine and carboplatin: effective outpatient chemotherapy for advanced non-small cell carcinoma of the lung. Clin Oncol 13: 483-487
Gridelli C (2001) The ELVIS trial: a phase III study of single-agent vinorelbine as first-line treatment in elderly patients with advanced non-small cell lung cancer. Elderly Lung Cancer Vinorelbine Italian Study. Oncologist 6(Suppl 1): $4-7$

Gridelli C, Perrone F, Cigolari S, Manzione L, Piantedosi FV, Barbera S, Piazza E, Vinante O, Clerici M, Robbiati F, Bertetto O, Frontini L, Sacco C, Iaffaioli RV, Gallo C (2001) The MILES (Multicenter Italian Lung Cancer in the Elderly Study) Phase 3 Trial: Gemcitabine + Vinorelbine vs Vinorelbine and vs Gemcitabine in Elderly Advanced NSCLC Patients. Proc Am Soc Clin Oncol 20: 308a (abstract)

Jaakkimainen L, Goodwin PJ, Pater J, Warde P, Murray N, Rapp E (1990) Counting the costs of chemotherapy in a National Cancer Institute of Canada randomized trial in nonsmall-cell lung cancer. J Clin Oncol 8: 1301 - 1309

Janssen-Heijnen ML, Gatta G, Forman D, Capocaccia R, Coebergh JW (1998) Variation in survival of patients with lung cancer in Europe, 1985-1989. Eur J Cancer 34: $2191-2196$

Jelic S, Mitrovic L, Radosavljevic D, Elezar E, Babovic N, Kovcin V, Tomasevic Z, Kovacevic S, Gavrilovic D, Radulovic S (2001) Survival advantage for carboplatin substituting cisplatin in combination with vindesine and mitomycin C for stage IIIB and IV squamous-cell bronchogenic carcinoma: a randomized phase III study. Lung Cancer 34: 1-13

Johnson DH, Zhu J, Schiller JH, Belani C, Langer C, Krook J, Harrington D, Sandler A (1999) E1594-A Randomized Phase III Trial in Metastatic NonSmall Cell Lung Cancer (NSCLC)-Outcome of PS 2 Patients (Pts): An Eastern Cooperative Group Trial (ECOG). Proc Am Soc Clin Oncol 18: 1779 (abstract)

Kelly K, Crowley J, Bunn Jr PA, Presant CA, Grevstad PK, Moinpour CM, Ramsey SD, Wozniak AJ, Weiss GR, Moore DF, Israel VK, Livingston RB, Gandara DR (2001) Randomized phase III trial of paclitaxel plus carboplatin versus vinorelbine plus cisplatin in the treatment of patients with advanced non - small-cell lung cancer: a Southwest Oncology Group trial. J Clin Oncol 19: 3210-3218

Klastersky J, Sculier JP, Lacroix H, Dabouis G, Bureau G, Libert P, Richez M, Ravez P, Vandermoten G, Thiriaux J, Cordier R, Finet C, Berchier MC, Sergysels R, Mommen P, Paesmans M (1990) A randomized study comparing cisplatin or carboplatin with etoposide in patients with advanced non-small-cell lung cancer: European Organization for Research and Treatment of Cancer Protocol 07861. J Clin Oncol 8: 1556-1562

Klastersky J, Sculier JP, Ravez P, Libert P, Michel J, Vandermoten G, Rocmans P, Bonduelle Y, Mairesse M, Michiels T, Thiriaux J, Mommen P, Dalesio O (1986) A randomized study comparing a high and a standard dose of cisplatin in combination with etoposide in the treatment of advanced non-small-cell lung carcinoma. J Clin Oncol 4: 1780-1786

Kosmidis PA, Bacoyiannis C, Mylonakis N, Demopoulos MA, Dimitriadis K, Kalofonos HP, Samantas E, Skarlos D, Fountzilas G, Tsavdaridis D, Papakostas P, Pavlakis G, Pavlidis N (2000) A Randomized Phase III Trial of Paclitaxel Plus Carboplatin Versus Paclitaxel Plus Gemcitabine in Advanced Non Small Cell Lung Cancer (NSCLC). A Preliminary Analysis. Proc Am Soc Clin Oncol 19: 488a (abstract)

Le Chevalier T, Brisgand D, Douillard JY, Pujol JL, Alberola V, Monnier A, Riviere A, Lianes P, Chomy P, Cigolari S (1994) Randomized study of vinorelbine and cisplatin versus vindesine and cisplatin versus vinorelbine alone in advanced non-small-cell lung cancer: results of a European multicenter trial including 612 patients. J Clin Oncol 12: 360-367

Le Chevalier T, Brisgand D, Soria JC, Douillard JY, Pujol JL, Ruffie P, Aberola V, Cigolari S (2001) Long term analysis of survival in the European randomized trial comparing vinorelbine/cisplatin to vindesine/cisplatin and vinorelbine alone in advanced non-small cell lung cancer. Oncologist 6(Suppl 1): $8-11$

Lilenbaum R, Herndon J, List M, Desch C, Watson D, Holland J, Weeks J, Green M (2001) Single-agent versus combination chemotherapy in advanced non small cell lung cancer: A CALGB randomized trial of efficacy, quality of life, and cost-effectiveness. Eur J Cancer 37(Suppl 6): S153 (abstract)

Non-small Cell Lung Cancer Collaborative Group (1995) Chemotherapy in non-small cell lung cancer: a meta-analysis using updated data on individual patients from 52 randomised clinical trials. Br Med J 311: 899-909

Pasquini E, Tassinari D, Nicolini M, Gianni L, Oliverio G, Tononi A, Papi M, Drudi G, Panzini I, Ravaioli A (1998) Gemcitabine as a single agent in the treatment of elderly patients with stage IIIb and IV non-small cell lung cancer; preliminary results of an Italian multicentre phase II study. Ann Oncol 9(Suppl 4): 154 (abstract) 
Perng RP, Chen YM, Ming-Liu J, Tsai CM, Lin WC, Yang KY, Whang-Peng J (1997) Gemcitabine versus the combination of cisplatin and etoposide in patients with inoperable non-small-cell lung cancer in a phase II randomized study. J Clin Oncol 15: 2097-2102

Ramsey SD, Moinpour CM, Lovato LC, Grevstad PK, Kelly K, Presant C (2000) An Economic Analysis of Southwest Oncology Group Trial S9509: Cisplatin/Vinorelbine vs. Carboplatin/Paclitaxel for Advanced Non Small Cell Lung Cancer. Proc Am Soc Clin Oncol 19: 489a (abstract)

Ransom M, Davidson N, Nicolson M, Falk S, Carmichael J, Lopez P, Anderson H, Gustafson N, Jeynes A, Gallant G, Washington T, Thatcher N (2000) Randomized trial of paclitaxel plus supportive care versus supportive care for patients with advanced non-small-cell lung cancer. J Natl Cancer Inst 92: $1074-1080$

Ricci S, Antonuzzo A, Galli L, Tibaldi C, Bertuccelli M, Lopes Pegna A, Petruzzelli S, Algeri R, Bonifazi V, Fioretto ML, Orlandini C, Conte PF (2000) Gemcitabine monotherapy in elderly patients with advanced nonsmall cell lung cancer: a multicenter phase II study. Lung Cancer 27: $75-80$

Rodriguez J, Pawel J, Pluzanska A, Gorbounova V, Fossella F, Kaukel E, Mattson K, Millward M, Kim YS, Gamza F, Berille J, Belani CP (2001) A Multicenter, Randomized Phase III Study of Docetaxel + Cisplatin (DC) and Docetaxel + Carboplatin (DCB) Vs. Vinorelbine + Cisplatin (VC) in Chemotherapy-Naive Patients with Advanced and Metastatic Non-Small Cell Lung Cancer. Proc Am Soc Clin Oncol 20: 314a (abstract)

Roszkowski K, Pluzanska A, Krzakowski M, Smith AP, Saigi E, Aasebo U, Parisi A, Pham Tran N, Olivares R, Berille J (2000) A multicenter, randomized, phase III study of docetaxel plus best supportive care versus best supportive care in chemotherapy-naive patients with metastatic or nonresectable localized non-small cell lung cancer (NSCLC). Lung Cancer 27: $145-157$

Ruckdeschel JC, Finkelstein DM, Ettinger DS, Creech RH, Mason BA, Joss RA, Vogl S (1986) A randomized trial of the four most active regimens for metastatic non-small-cell lung cancer. J Clin Oncol 4: 14-22

Sacristan JA, Kennedy-Martin T, Rosell R, Cardenal F, Anton A, Lomas M, Alberola V, Massuti B, Carrato A, Minshall M (2000) Economic evaluation in a randomized phase III clinical trial comparing gemcitabine/cisplatin and etoposide/cisplatin in non-small cell lung cancer. Lung Cancer 28: $97-107$

Sandler AB, Nemunaitis J, Denham C, von Pawel J, Cormier Y, Gatzemeier U, Mattson K, Manegold C, Palmer MC, Gregor A, Nguyen B, Niyikiza C, Einhorn LH (2000) Phase III trial of gemcitabine plus cisplatin versus cisplatin alone in patients with locally advanced or metastatic non-smallcell lung cancer. J Clin Oncol 18: $122-130$

Scagliotti GV, De Marinis F, Rinaldi M, Crinò L, Gridelli C, Ricci S, Bianco AR, Boni C, Marangolo M, Failla G, Adamo V, Altavilla G, Ceribelli A, Clerici M, Di Costanzo F, Frontini L, Tonato M (2001) Phase III Randomized Trial Comparing Three Platinum-Based Doublets in Advanced Non-Small Cell Lung Cancer. Proc Am Soc Clin Oncol 20: 308a (abstract)

Schiller JH, Harrington D, Sandler A, Belani C, Langer C, Krook J, Johnson DH (2000) A Randomized Phase III Trial of Four Chemotherapy Regimens in Advanced Non-Small Cell Lung Cancer (NSCLC). Proc Am Soc Clin Oncol 19: 1a (abstract)
Schiller JH, Harrington D, Belani CP, Langer C, Sandler A, Krook J, Zhu J, Johnson DH (2002) Comparison of four chemotherapy regimens for advanced non-small-cell lung cancer. $N$ Engl J Med 346: $92-98$

Shepherd FA, Dancey J, Ramlau R, Mattson K, Gralla R, O'Rourke M, Levitan N, Gressot L, Vincent M, Burkes R, Coughlin S, Kim Y, Berille J (2000) Prospective randomized trial of docetaxel versus best supportive care in patients with non-small-cell lung cancer previously treated with platinum-based chemotherapy. J Clin Oncol 18: 2095-2103

Smith IE, O'Brien ME, Talbot DC, Nicolson MC, Mansi JL, Hickish TF, Norton A, Ashley S (2001) Duration of chemotherapy in advanced non-small-cell lung cancer: a randomized trial of three versus six courses of mitomycin, vinblastine, and cisplatin. J Clin Oncol 19: $1336-1343$

Smith TJ, Hillner BE, Neighbors DM, McSorley PA, Le Chevalier T (1995) Economic evaluation of a randomized clinical trial comparing vinorelbine, vinorelbine plus cisplatin, and vindesine plus cisplatin for non-small-cell lung cancer. J Clin Oncol 13: 2166-2173

Socinski MA, Kies M, Schell MJ, Bakri KM, Lee JM, Lee JH, Tynan MT, Peterman A (2001) Duration of Therapy in Stage IIIB/IV Non-Small Cell Lung Cancer (NSCLC): A Multi-Institutional Phase III Trial. Proc Am Soc Clin Oncol 20: 309a (abstract)

Tan E-H, Souquet PJ, Rodrigues Pereira J, Van Klaveren R, Price A, Gatzemeier U (2001) Glob 1: Final Results of a Prospective Randomized Phase II Trial Comparing Vinorelbine and Cisplatin (NP) Versus Vinorelbine, Ifosfamide, and Cisplatin (NIP) in Metastatic Non Small Cell Lung Cancer (NSCLC) Patients. Proc Am Soc Clin Oncol 20: 326a (abstract)

ten Bokkel Huinink WW, Bergman B, Chemaissani A, Dornoff W, Drings P, Kellokumpu-Lehtinen PL, Liippo K, Mattson K, von Pawel J, Ricci S, Sederholm C, Stahel RA, Wagenius G, Walree NV, Manegold C (1999) Single-agent gemcitabine: an active and better tolerated alternative to standard cisplatin-based chemotherapy in locally advanced or metastatic nonsmall cell lung cancer. Lung Cancer 26: 85-94

Thongprasert S, Sanguanmitra P, Juthapan W, Clinch J (1999) Relationship between quality of life and clinical outcomes in advanced non-small cell lung cancer: best supportive care (BSC) versus BSC plus chemotherapy. Lung Cancer 24(1): 17-24

Van Meerbeeck JP, Smit EF, Lianes P, Schramel F, Lenz M, Debruyne C, Giaccone G (2001) A EORTC Randomized Phase III Trial of Three Chemotherapy Regimens in Advanced Non-Small Cell Lung Cancer. Proc Am Soc Clin Oncol 20: 308a (abstract)

Vansteenkiste J, Vandebroek J, Nackaerts K, Weynants P, Valcke Y, Verresen D, Devogelaere R, Marien S, Bosquee L, Galdermans D, Delobbe A, Humblet Y, Dams N (2000) Symptom Control in Advanced Non-Small Cell Lung Cancer (NSCLC): A Multicenter Prospective Randomized Phase III Study of Single Agent Gemcitabine (GEM) Versus Cisplatin-Vindesine (PV). Proc Am Soc Clin Oncol 19: 488a (abstract) 